\title{
Rethinking business models in the Great Depression: the failure of America's vacuum cleaner industry
}

Article

Accepted Version

Scott, P. ORCID: https://orcid.org/0000-0003-1230-9040 (2019) Rethinking business models in the Great Depression: the failure of America's vacuum cleaner industry. Business History Review, 93 (2). pp. 319-348. ISSN 2044-768X doi: https://doi.org/10.1017/S0007680519000679 Available at https://centaur.reading.ac.uk/81509/

It is advisable to refer to the publisher's version if you intend to cite from the work. See Guidance on citing.

To link to this article DOI: http://dx.doi.org/10.1017/S0007680519000679

Publisher: Cambridge University Press

All outputs in CentAUR are protected by Intellectual Property Rights law, including copyright law. Copyright and IPR is retained by the creators or other copyright holders. Terms and conditions for use of this material are defined in the End User Agreement.

www.reading.ac.uk/centaur 
Central Archive at the University of Reading

Reading's research outputs online 


\section{Prisoners of their business models: the decline of America's leading vacuum cleaner firms during the Depression-era}

We examine the factors leading to the onset of organizational rigidities in the dominant vacuum cleaner firms of the 1920s, Hoover and Eureka. Strategies aimed at strengthening organizational commitment, in conjunction with low levels of organizational diversity - owing to managerial hierarchies dominated by men recruited from the sale force - restricted organizational flexibility and adaptability, while accentuating resistance to change. In conjunction with core competencies that largely reflected conditions in their previous rapid growth phases, organisation rigidity left both firms vulnerable to the new conditions of the Depression, including product and value chain innovation by a new entrant, Electrolux.

\section{Acknowledgements}

I thank the Centre for Business History, Stockholm; Hagley Museum and Archives; Hoover Historical Centre, North Canton, Ohio; McLean County Museum of History, Bloomington Illinois; MiSci Museum, Schenectady, New York; Wright State University Special Collections and Archives; and Tom Gasko, for access to sources. Thanks are also due to Leslie Hannah, Karina Pavlisa, Megan Pellegrino, James Walker, participants of the IBS seminar series at the University of Reading's Henley Business School, and three anonymous referees, for comments on earlier drafts. Any errors are mine. 


\section{Introduction}

The frequent inability of long-established corporations to effectively respond to radical changes in market conditions, or disruptive innovation, is a well-established phenomenon. The dynamic capabilities literature suggests that institutionalised capabilities may lead to "incumbent inertia" to environmental changes, with even minor innovations having the potential to undermine the value of the firm's deeply-embedded knowledge. ${ }^{\text {i }}$ This has been explained in terms of a sclerotic process whereby interdependencies between individual elements of the business model grow and harden across time, making changes to any element progressively more difficult. ${ }^{\text {ii }}$

A connected phenomenon is growing organisational homogeneity, which can reduce internal criticism of the business model. ${ }^{\text {iii }}$ Homogeneity is likely to be particularly strong in situations where managers are promoted from workers with common functional and skill backgrounds, especially where other types of diversity, such as gender or ethnicity, are weak or absent. ${ }^{\text {iv }}$ Alan Raucher identified such problems in inter-war American chain stores, where higher management positions were generally filled by people who had entered as trainee store managers. ${ }^{\mathrm{v}}$

This article examines the causes of managerial inertia in consumer durables firms that used their own direct salesforces to sell their products, through case studies of the two largest vacuum firms of the 1920s, Hoover and Eureka. Direct sales firms were particularly vulnerable to managerial homogeny. Their workforces and, especially, their white-collar staff, were dominated by salesmen, while sales-related functions represented the bulk of their managerial positions and carried particularly high status and influence. Moreover, chronic labour turnover and a geographically dispersed salesforce led to heavy investments in "selling" the firm's methods and "mission" to their employees - to strengthen organizational 
commitment. ${ }^{\mathrm{vi}}$ While strong organizational commitment has a range of positive impacts, it can also act to restrict organizational flexibility, innovation and adaptability, while promoting blind faith in the firm's established business model; particularly those elements that are perceived to be the distinctive managerial innovations underpinning its earlier success. ${ }^{\text {vii }}$

After briefly discussing the rise of the vacuum cleaner industry, this paper explores the strategies used to develop organisational commitment and conformity to the dominant firms' increasingly standardised business models. It then focuses on how, from the second half of the 1920s, they faced growing organisational rigidity, in areas such as sales support, staff training and motivation, and organisational goals-setting. Such problems intensified during the Depression, accentuated by the rise of a new foreign entrant - Electrolux. We then use data from a detailed 1939 investigation of Hoover by consultant engineers Ford, Bacon \& Davis to show how Hoover failed to modify its business model to counter Electrolux's competitive threat and over-invested in sales support activities to such an extent that it had insufficient profits to match Electrolux's sales commission rates.

\section{The rise of the door-to-door vacuum cleaner manufacturing and sales firm}

The first practicable powered vacuum cleaners appeared at the beginning of the twentieth century and by 1914 had been transformed into portable, electrically-powered, appliances suitable for the housewife. Until 1924 entry to the sector was tightly controlled under an agreement between the holder of the industry's fundamental (Kenney) patent and the Vacuum Cleaner Manufacturers Association (representing early licensees of the Kenney patent), which effectively blocked the granting of further licenses and, therefore, market entry. This led to the early industry being characterised by high profits, high and stable prices, and non-price competition. ${ }^{\text {viii }}$ 
Most major inter-war vacuum manufacturers were established during this period. Hoover owes its origins to James Murray Spangler, an asthmatic janitor who devised a crude portable electric vacuum in 1907. He sold the idea to W. H. "Boss" Hoover, a man of considerable sales acumen, who started manufacturing cleaners in 1908 at his leather-goods works in North Canton, Ohio. ${ }^{\text {ix }}$ America's second most important vacuum manufacturer of the 1920s, Eureka, was established by the salesman Fred Wardell, who marketed the Eureka Model 1 from 1909 and, in 1910, founded the Eureka Vacuum Cleaner Co. in Detroit. ${ }^{\mathrm{x}}$ Most other major manufacturers, such as Frantz Premier Vacuum Cleaner Co. (founded in 1910); Apex Electric Manufacturing Co. (1913) and P.A. Geiger Co. (1905), were also based in or around Ohio, reflecting a geographical clustering evident in other consumer durables sectors, such as washing machines (Iowa, especially Newton) and automobiles (south east Michigan).

National output rose from 702,000 units, retailing at $\$ 42,120,000$, in 1919 to $1,396,000$, retailing at $\$ 64,811,000$, in 1929 . During the 1920 s Hoover and Eureka vied for market leadership, collectively representing 40 per cent of national unit sales in 1921 and 41 per cent in 1927. Even after the expiration of the Kenney patent early entrants continued to dominate (until the rise of Electrolux in the 1930s), owing to their development of "detail" patents that provided brand-specific advantages, and - more importantly - their early development of large salesforces that typically greatly outnumbered their production staff.

The 1920s provided a rapidly-growing potential market, owing to the spread of household electrification and the "scientific homemaking" movement, which advocated using scientific management methods to improve the efficiency of the homemaker, via a combination of modern housework techniques and new labour-saving technologies. ${ }^{\mathrm{xi}}$ Consumer durables were presented as taking the drudgery out of housework, thus enabling middle-class housewives to do their own housework without transgressing the social norm that heavy or dirty household tasks were unladylike. ${ }^{\text {xii }}$ Scientific homemaking both promoted 
the new durables and legitimized the salesman's call at the door, as he could introduce himself as an instructor on methods to improve household efficiency. Door-to-door selling was a key promotional device for other electric durables, such as radios, refrigerators, and washing machines, though these tended to rely more heavily on local retailers' salesmen, whereas vacuums were primarily marketed by salesmen recruited, trained, monitored, and paid by the manufacturers. ${ }^{\text {xiii }}$

Vacuum firms were sales-driven companies. As Hoover's official history noted, “the sales department is the most important part of an operation like this."xiv The largest firms also placed substantial emphasis on product quality and innovation, though this reflected their need to develop strong proprietary features, so that salesmen could trumpet superiority over rival brands. Hoover's principal selling point was its patented cleaning system - "carpet agitation" - promoted with the slogan "It Beats As It Sweeps As It Cleans". ${ }^{x v}$ In 1926, when their original agitator patents expired, Hoover introduced "positive agitation" - with replaceable brushes and a rigid metal beater bar spiralled around the roller to more efficiently remove dirt. Eureka stressed its variety of innovative attachments, including paint spraying and hair drying functions. ${ }^{x v i}$ Such "features" were underpinned by heavy investments in research and development. Hoover's Experimental Department, established in 1919 to test materials and conduct R\&D, employed 100 people by $1938 .{ }^{x v i i}$

Rather than following the Fordist strategy of achieving market dominance by undercutting competitors' prices, Hoover and Eureka followed the practice of earlier market leaders in standardised machinery, such as Singer and McCormick Harvesting Co.. These set prices at the top of the range for their sectors, capitalising on any scale economies in production by investing lavishly in sales and marketing. ${ }^{\text {xviii }}$ Indeed, despite substantial rises in output, vacuum retail prices and costs actually rose in real terms during the 1920s. Leading 
manufacturers' avoidance of price competition was also evident in other consumer durables sectors, such as refrigerators, washing machines, and (during the 1920s) radio. ${ }^{\text {xix }}$

Vacuum manufacturers soon learned that the best way to demonstrate brand-specific advantages, and overcome strong consumer inertia and resistance, was door-to-door selling. Hoover moved to direct sales in around 1910, after observing that their retailers were not pushing Hoovers any more than the other products they stocked. They then placed salesmen in each dealer's store - what became known as the "resale system". In return for this service dealers accepted a lower commission ( 15 per cent, rather than the customary 33.3 per cent of the selling price); the remaining 18.3 per cent paying the salesman and the costs of his training and management. Then, from 1921, Hoover moved to a strategy of house-to-house canvassing (rather than only going to people's homes if asked for a demonstration), though the retailer was still paid the 15 percent commission - for providing sales leads, allowing salesmen to call on prospects using its name, stocking inventory, and providing the instalment credit on which most vacuums were sold. ${ }^{\mathrm{xx}}$

The major firms developed large sales forces, organised geographically, into regions and territories. For example, in May 1927 Eureka's national sales operation comprised four regional divisions, managing 30 branch territories. Each territory was structured into a wholesale section (serving the conventional store trade) and a retail section, selling under the resale system, as shown in Figure 1. ${ }^{\mathrm{xxi}}$ At this time Eureka employed 2,835 men in its outside sales organisation, while its total factory workforce numbered 625 . In other words, it took 4.5 people to sell the output of each production worker (excluding the contribution of the independent retailers with whom their salesforce collaborated). ${ }^{x x i i}$ Direct sales dominated total selling costs, though the major companies also invested substantially in advertising, to boost brand recognition and assert superior performance and proprietary features in advance of the salesman's call. ${ }^{\text {xxiii }}$ 


\section{[Figure 1 near here]}

\section{Corporate strategies for cementing organizational commitment}

One of the greatest challenges facing vacuum companies was the recruitment and retention of sales staff, owing to the job's irregular (and often low) income, together with its low status - even among salesmen. Ford, Bacon \& Davis found that some 90 per cent of applicants for Hoover salesmen's jobs were people without money, who desired security and only considered sales because they could not find jobs offering a similar guaranteed income. Conversely, "Men who have been successful as salesmen in other lines will not take a job selling vacuum cleaners as they consider it beneath them. The public is inclined to look down on the work... so the fear of ridicule on the part of applicants is one of the principal things to be overcome."xxiv

Selling vacuums lacked the romance of high profile "masculine" products (such as cars) and was considered more distasteful even than washing machines - which in turn was more distasteful than selling refrigerators or radios. ${ }^{\mathrm{xxv}}$ The major firms thus devoted considerable time and resources to "selling" the job to current and prospective salesmen. In addition to attracting salesmen through adverts, which either carried the local dealer's name or were "blind" (not specifying the employer or the exact nature of the work), Hoover also used its existing salesmen, managers, and dealers as recruiting agents. In the mid-1920s around 50 per cent of Hoover salesmen were recruited through newspaper advertising; 25 per cent through personal contact with the sales manager; 10 per cent through Hoover salesmen; 5 per cent through Hoover dealers; 5 per cent through Hoover users, and the remaining 5 per cent through other sources. ${ }^{\text {xxvi }}$ Similar methods were still being used in the late 1930s, though 
there appears to have been more emphasis on "get-a-man" campaigns, whereby prizes were offered to salesmen who brought in new recruits. ${ }^{\text {xxvii }}$

Manpower was viewed as the key determinant of sales. As a 1934 Hoover sales managers’ manual emphasised, “A Senior Manager's major responsibilities are - building manpower and developing Field Managers to absorb manpower... the Senior Manager who is unable to perform these two major operations, falls short of fulfilling his obligations." ${ }^{\text {xxviii }}$ This emphasis on recruitment reflected chronic sales labour turnover ranging, in 1939, from 100 per cent per annum for Hoover's 1,500 leading salesmen who generated 80 per cent of sales to about 500 per cent for the other salesmen on their list. Leading salesmen earned around \$31 per week and others regarded as "productive" about $\$ 13$ per week; while the rest - numbering some 2,500 - 3,000 - sold only around one cleaner per month, on which they would earn around $\$ 13$. $^{\text {xxix }}$

High labour turnover compelled sales managers to undertake two conflicting tasks, infusing the salesforce with positive messages - the value of the product, their sense of mission, and their ability to achieve sales goals - while avoiding heavy investments of time in salesmen who were never going to make the grade. ${ }^{\mathrm{xx}}$ Hoover relied on payment by commission to weed out weaker salesmen, while seeking to support stronger salesmen through further training, sales quotas, competitions, and other incentives. Pressure to achieve targets sometimes tempted salesmen to use dubious, or even criminal, tactics and - like the chain stores - the vacuum firms found it necessary to develop systems to identify and address opportunistic behavior. ${ }^{\text {xxi }}$ Hoover's monitoring included looking out for improbably high sales figures, which might reflect dubious methods, while Eureka employed a detective to check on their salesmen. ${ }^{\text {xxxii }}$ 
Problems of salesforce monitoring and motivation were accentuated by the fact that door-to-door salesmen and their field managers were physically distanced from top managers, - a problem also faced by chain stores. ${ }^{\text {xxxiii }}$ However, the vacuum companies felt this more acutely, owing to chronic labour turnover and the lower typical calibre of their recruits. The solutions developed to deal with this problem were, in turn, broadly similar to those embraced by other sales-orientated firms - based on a behaviouralist set of management theories, later formalised by the "human relations" school. ${ }^{\text {xxiv }}$

Hoover's system had strong similarities with the "inspirational" management formula pioneered by John H. Patterson at National Cash Register from the 1880s, which also acted as the blueprint for Frigidaire's early direct selling operation. ${ }^{\mathrm{xxv}}$ This encompassed both how sales managers communicated with their salesmen and the broader "positioning" of Hoover as a company with a mission and social conscience. Techniques pioneered by Patterson that were adopted by Hoover included sales quotas (and clubs for salesmen who made quota); systematic sales training; the use of detailed scripts to standardise the sales process; contests; motivational sales conventions; a model factory with a cafeteria, hospital, and recreational facilities; and - more broadly - a strategy of combining material incentives for staff with "purposeful" (symbolic) incentives. ${ }^{\text {xxxvi }}$ Eureka (on the basis of the much thinner archival evidence for this company) appears to have adopted broadly similar strategies. ${ }^{\text {xxxvii }}$

Managers were expected to employ interpersonal skills to identify salesmen’s motivations and align their personal goals with those of the company. ${ }^{\text {xxviii }}$ Meanwhile salesmen's masculine credentials were boosted by stressing their sales “mission", the competitive nature of their calling, and the rewards for success - encompassing immediate financial rewards, symbolic incentives, and promotion prospects. ${ }^{\text {xxix }}$ Hoover and Eureka emphasised their culture of meritocratic internal promotion, for example by trumpeting the success of senior managers who had risen through the ranks. While Hoover made some 
senior appointments externally, especially during its early rapid-growth phase, it increasingly focused on internal promotion. In 1927 Bill Steele - a former medical student who had taken a summer job selling vacuums for Hoover and never returned to his studies - became the first person to rise from the position of salesman to Director of Sales, where he pursued a policy of internal promotion. ${ }^{\mathrm{xl}}$ Hoover also emphasised the salesmanship credentials of its top managers. For example, during the 1920s Hoover's President, Herbert W. Hoover Sr., introduced the "sales pilgrimage": all executives who had any connection with sales were required to sell vacuums door-to-door for one week each year, in an unknown area with no leads or help, and make the standard sales quota. ${ }^{\text {xli }}$

Vacuum manufacturers also invested intensively in symbolic methods of boosting staff loyalty, effort, and conformity. This included building a "social" element into the firm's dealings with its sales force. Francesca Carnevali has shown how collective social events, involving rituals such as parades, fancy dress, and other forms of pageantry and associational activity, assisted the development of nineteenth century trade associations as "social structures," by embedding their members in a "community" and thereby tempering opportunistic behaviour. ${ }^{\text {xlii }}$ From the late nineteenth century companies also began sponsoring picnics, dances, and other social events, together with the provision of social and recreational facilities, to present themselves as a community, harmonize employee relations, raise morale, and strengthen the bond between employee and firm. ${ }^{\text {xlii }}$

Such strategies were more problematic for companies with a geographically dispersed workforce, who could not be expected to travel several hundred miles for a company picnic. Hoover therefore focused on large annual events to bring together its salesforce. In 1921 Hoover held its first "International Sales Convention". Managers and salesmen alike were accommodated in "Hoover Camp," a tented city for 160 men comprising their entire managerial workforce, together with those salesmen who had met their "Maximen grade" 
sales target. The event was designed to downplay differences in rank and emphasise the esprit de corps of the sales team. As an unpublished firm history notes, "The men slept, ate, and bathed under canvass. This event marks the time when the real Hoover spirit was brought to full flower". xliv

The following year's convention was opened by a spectacular parade through North Canton, featuring costumed delegations from the field offices and elaborate floats representing the headquarters' departments. ${ }^{\text {xlv }}$ Then in 1923 the third international convention saw a more impressive parade, with almost 2,000 participants - including Hoover's entire factory and office personnel in costume. ${ }^{\text {xlvi }}$ Subsequent conventions during the 1920 s witnessed ever more elaborate pageantry and entertainments.

\section{[Figure 2 near here]}

The conventions served a number of important functions, including celebrating the organisation's values and acclaiming individual and collective success, to bolster salesforce commitment. ${ }^{x l v i i}$ They allowed successful salesmen opportunities to develop links with managers from field and headquarters operations, cemented by the shared experiences of the conventions' antics. They also provided opportunities for bonding between sales teams spanning the U.S.A., Canada, and much of Europe, including elements of "misrule": ritual events during which workers subverted the hierarchy in controlled settings, which were characteristic of sales conventions during this era. ${ }^{\text {xlviii }}$

For example, the 1927 convention witnessed the usual fireworks, treasure hunts, vaudeville nights, skits, kangaroo courts, and an incident where, after Director of Sales Steele had arranged to have the Director of Hoover's European sales organisation, M.C. Dizer, thrown in the swimming pool, "the entire European delegation induced the fully clothed $\mathrm{Mr}$ Steele that he should join Mr Dizer." ${ }^{\text {"lix }}$ Such public displays of community both helped to 
build group solidarity and assert group "legitimacy". This was particularly important for a form of selling that had low public status and was widely seen as "un-masculine" (as it involved demonstrating work generally done by the housewife or maid).

Co-ordinating the efforts of large sales teams required employees to share not only the corporation's goals, but its “ideology” (a group of driving ideas regarding their sales mission, often expressed as ethical principles, such as serving the community). ${ }^{\text {li }}$ Strong corporate ideologies and cultures boosted staff loyalty by instilling a sense of company "ownership" in the workforce. Loyalty was important for effort, retention, and probity, while also reducing the risk of salesmen betraying the firm's selling "system" to competitors. lii

Corporate ideologies were introduced to salesmen during their initial training and subsequently promoted through sales team meetings and sales manuals, flyers, and employee magazines. Hoover launched its first magazine, Hoover Sweepings, for its salesmen and dealers in 1911; one of the earliest issues included items on countering customers' objections, booklets available from its "Dealer's Cooperation Department," and a report on a recent dealer sales contest. ${ }^{\text {lii }}$ Hoover's magazines (which later branched to serve individual constituencies, such as its executives (Hoover Manager) and its retailers (Hoovergrams), served not only to communicate information, but to humanize and harmonize the salesman's relationship with the company by celebrating the activities and achievements of the workforce and emphasising the company's internal culture and sense of community. ${ }^{\text {liv }}$ This boosted the "affective commitment" of the salesforce, a particularly useful strategy in a sector where direct monitoring was problematic. ${ }^{\text {lv }}$

Hoover was careful to ensure that relationships between sales managers and their salesmen were also embedded in a strong social milieu. A 1925 field managers' manual began with the following advice on sales meetings: 
Make of each meeting a good fellowship-get-together that will help to cement the bonds of friendliness and good will for every member of your organization. Wherever possible, it is always a good idea to have some kind of music at sales meetings. Let some fellow volunteer with his banjo, guitar, fiddle, or mouth organ. Begin each meeting with a rousing and enthusiastic song session. Have plenty of singing. ${ }^{\text {lvi }}$

The manual also advised that, "Occasionally the meetings should take a distinctly social turn, at which time not only the woman demonstrators, office people, and representatives should be present, but the wives, sweethearts and mothers should be welcome and urged to attend. This creates a spirit that builds for permanency... It will carry the Hoover spirit of loyalty and enthusiasm into the home life of your salesmen and will do more good than a dozen lectures from your table." "lvii It also emphasised the importance of serving food and drinks (ideally made up on site) in fostering "Informality" and "Sociability". lviii Staff were encouraged to compose "Hoover songs", set to the tune of popular hits, for singing at these events.

Fostering organisational commitment involved developing a system that was an "assemblage" of various components, configured to achieve these objectives. ${ }^{\text {lix }}$ These included appropriate incentive systems; carefully specified and standardised training methods; staff magazines; an inspirational and motivational management style; and social events ranging from regular field-based meetings to annual grand conventions. As Kenneth Lipartito notes, parades, meetings, company songs and so forth are "expressive" activities, contributing to the assemblage that could be called Hoover's "system" precisely because they were not reducible to economic incentives, but instead shaped shared identities. ${ }^{1 \mathrm{x}}$ Hoover's portfolio of commitment strategies evolved partly through a process of trial and error, but progressively hardened into an integrated system, owing to entrenched interdependencies 
between their various organisational commitment strategies, and between these strategies and other elements of their business model. ${ }^{\text {lxi }}$

Hoover's selling formula and sales management model were also becoming increasingly standardised. This diffused what Hoover and Eureka perceived to be best practice, but decreased the scope for individual innovation. Salesmen were given rehearsed arguments, a rigid demonstration set out in a series of predetermined steps, and set responses to common objections by prospective customers. ${ }^{\text {Ixii }}$ For example, in June 1924 Hoover introduced a "Standard" vacuum sales pitch via in The Hoover Sale, a booklet setting out a 28 step demonstration, said to have been compiled from contributions by its sales force. In 1932 the company sought further standardisation, via a new "Standard Way" plan of predetermined sales steps - again emphasising that it had been distilled from "months spent in the field accompanying some of our most consistently successful salesmen". ${ }^{x i i i}$ By 1936 Hoover's sales manual covered 47 pages, largely comprising step-by-step sales dialogue. ${ }^{\text {lxiv }}$

A recurring theme was the importance of persistence - wearing down the prospect's resistance by a series of prepared demonstrations, to be continued until the sale was closed. As The Standard Way counselled, "Keep on Demonstrating until you have either sold The Hoover or exhausted every possibility of closing the sale." Ixv Similarly, Steps had fifteen pages under the heading "KEEP ON SELLING", beginning with the advice "Every demonstration results in a sale - either you sell the prospect or the prospect sells you. The prospect has many excuses to sell you, any one of which, if you buy, defeats your sale."lxvi This echoed a contemporary industry view that salesmen principally competed against their prospects, pitting their willpower, assertiveness, and above all persistence against (typically) that of the housewife. ${ }^{\text {lxvii }}$ 
Vacuum salesmen appear to have been universally male (with the exception of female canvassers, used by a few firms to arrange the salesman's call). This may have reflected the need to haul a heavy cleaner door to door, though it was true of most speciality direct sales work at this time. Employing women would have run counter the masculine sales cultures that Hoover, Eureka, and other sales-dominated companies sought to create and might have challenged their emphasis on meritocratic promotion - at a time when women were almost entirely excluded from corporate management roles. ${ }^{\text {lxviii }}$

\section{Maturity, rising costs, and the new competition}

The dominant vacuum firm business model, based on an implicit assumption that sales maximisation was synonymous with success, led to the use of increasingly high cost marketing methods that inflated list prices and produced decreasing returns to investment in sales support and manpower by the late 1920s. For example, Hoover's national advertising spend per vacuum sold rose from an average of $\$ 1.00$ over $1919-23$ to $\$ 1.69$ over $1924-27$ and \$2.15 over 1928-30. ${ }^{\text {lxix }}$ More comprehensive data for Eureka are shown in Figure 3. From $1921-23$ a rise in annual net sales from $\$ 3,107,000$ to $\$ 8,215,000$ was matched by a fall in the ratio of costs to sales and a major increase in profits. However, despite further substantial growth in net sales, to $\$ 12,780,000$ by 1927 , the ratio of costs to sales rose from 73.86 to 82.56 per cent, while profit rates declined markedly and costs per unit rose from $\$ 29.58$ to $\$ 39.00$. This culminated in a fall in net sales to $\$ 10,100,000$ in 1928 and, despite some recovery in 1929, Eureka's profit ratio remained lower than any year since 1923, while its cost ratio was higher than any year from 1923-27.

\section{[Figure 3 near here]}

While more disaggregated data are not available, it seems extremely likely that total costs were being driven up by sales-related activities, rather than production costs. Eureka 
had a trend of rising dollar and unit sales (during a period of only moderate inflation), while the sector demonstrated a long-term decline in production costs, relative to total costs. Production costs were estimated at 51.7 per cent of all costs for the three largest vacuum manufacturers in 1921, but had declined to only 27.6 per cent of Hoover's total costs in 1938 (excluding dealer discounts). ${ }^{\mathrm{lxx}}$

Yet there is no evidence of internal criticism regarding rising sales support and manpower costs. Hoover and Eureka had built up hierarchies of sales executives, promoted mainly from the ranks. Young companies have a tendency to recruit people who fit well with the corporate culture shaped by the skills, aptitudes, and values of their founders; for example Henry Ford, a, "gifed tinkerer... surrounded himself with other tinkerers, twenty years younger than he was, but like Ford without formal education." "'xxi Policies of internal promotion accentuated this bias by restricting the pool of candidates to those that had already been pre-screened to match the firm's dominant discipline and values. ${ }^{\text {lxxii }}$ Moreover, it deprived them of the benefits of external hiring - which has been identified as a significant mechanism for disrupting established routines and facilitating change. The benefits of external hires are found to increase with the age of the corporation, as they stimulate explorative activities, diminish "groupthink" and resistance to change, and introduce "distant knowledge" derived from working in other organizations. . $x x i i i^{\text {. }}$

Executive conformity was accentuated by their training, indoctrination into the Hoover culture, and - as junior managers - their task of convincing salesmen that the firm's products, system, and extensive investments in sales support activities constituted the optimum business model. In a sector where belief in the product and the sales formula took on almost religious connotations, scepticism of the orthodox approach could easily be interpreted as heresy. The scope for criticism had been further reduced by the introduction of increasingly standardised and bureaucratised salesforce training procedures, which prized 
strict conformity to their systems. This parallels Raucher's findings that economic maturity brought with it organizational rigidity for the variety store chains, with executives ingrained in their firm's system struggling to react to the new conditions of the late 1920s and the Depression era. ${ }^{\text {lxxiv }}$ Hoover's self-image as a sales-orientated organisation also inhibited challenges to the firm's dominant sales logic from staff in other managerial specialisms, such as accounting. Scholars have identified a tendency for companies to disproportionately attract, reward, and listen to people with skills reflecting their "dominant discipline", or function, while those from functions seen as subordinate typically have weaker influence. ${ }^{1 \mathrm{xxv}}$

Christensen, Bartman, and Bever identify a tendency towards business model rigidity, owing to growing interdependencies between the model's individual elements, which leads to innovation focused around "sustaining innovations" - value-adding improvements to existing products for current target markets. ${ }^{\text {lxxvi }}$ This pattern was evident in Hoover, which focused on improvements to its upright cleaner format throughout the inter-war years. They also predict that when such investments no longer generate adequate additional profitability, costreducing innovations aimed at improving the efficiency of the business model will increasing dominate, as "the voice of the shareholders drowns out the voice of the customer". 1xxvii However, at Hoover these pressures were severely muted, as it was a private, family-owned, firm until 1943 and was headed by members of the Hoover family until 1966 (apart from John Frank Hattersley's brief term as President from 1951 until January 1954, when he was ousted following an acrimonious family battle). ${ }^{\text {xxviii }}$

During the 1920s vacuum manufacturers had faced an expanding market owing to rapid growth in the number of wired homes, together with rising prosperity, the escalating cost of domestic servants, and growing popular familiarity with powered domestic appliances. However, the Depression witnessed a dramatic fall in sales. From 1929 to 1933 annual unit sales of floor-type vacuum cleaners declined from 1,253,000 to 548,000, in 
contrast to refrigerators and washing machines, that had recovered beyond their 1929 unit sales. ${ }^{\text {lxix }}$ Conversely, vacuum manufacturers generally managed to maintain list prices, despite sharp price falls for most other durables, and witnessed relatively few corporate liquidations. However, the two leading firms of the 1920s, Hoover and Eureka, both witnessed severe falls in market share.

Eureka was by far the worst affected. In 1930 they employed an army of over 4,000 door-to-door salesmen, supported by 35 major branch offices in large U.S. cities, and 100150 sub-branches (sales offices) which ran the customer credit, stocked inventories, and supervised retailers working with Eureka under the resale plan. ${ }^{1 \times x x}$ Around 50 per cent of sales were made directly, around 25 per cent under the resale plan, and the remainder from dealers who purchased cleaners outright from the factory. The heavy costs of Eureka's branch network, inventories, and instalment accounts impacted on the prices of all their machines even those sold through conventional retail channels - as it was impractical to charge one price to final customers purchasing from a door-to-door salesman and a lower price for the same models sold through stores. ${ }^{1 \times x \times i}$ During the depression high costs were translated into huge losses. Eureka's sales had peaked in 1927 at $\$ 12,780,000$, generating a profit of $\$ 1,806,000$. However, sales fell sharply after 1929 - to $\$ 4,297,000$ in 1931 , with an annual loss of $\$ 1,163,000$. $^{\text {lxxxii }}$

Faced with potential bankruptcy, Eureka responded by terminating their main direct sales operation, closing their sub-branches, slashing their branch office staff, and focusing on sales via the resale system and through "distributor-dealers" who paid their own salesmen's commission and acted as wholesalers for local retailers. This gave them a tiny profit of $\$ 18,420$ for the first six months of 1932 , but on a drastically reduced turnover of only $\$ 1,360,360$ for the whole of 1932 . $^{\text {lxxiii }}$ Yet direct selling per. se. was not the real problem; a trade article noted that total 1933 vacuum sales were almost completely down to four 
companies - Hoover, Electrolux, Airway, and Premier -which relied on direct selling as their sole or (for Premier) main sales channel. Indeed Airway's strong door-door selling performance, despite raising its prices, was said to have exerted a strong demonstration effect on other manufacturers. ${ }^{\text {1xxiv }}$ Despite some improvement during the mid-1930s, Eureka's sales volume and profitability never recovered; over the four years preceding World War Two it had cumulative losses of $£ 1,200,000$, while its 1941 vacuum sales represented only seven per cent of the industry total. ${ }^{\operatorname{lxxxv}}$

Hoover avoided an existential crisis, but nevertheless faced a decline in market share to only 14.04 per cent of unit sales by 1939 and a crisis of profitability, as shown in Table 1. ${ }^{\text {xxxvi }}$ Operating profit had fallen continuously during the Depression, from 13.5 per cent of net sales to a low of -3.9 per cent in 1932 and, while it recovered over 1935-37, it remained below half the 1929 ratio. Net profit was markedly higher, presumably reflecting Hoover's extensive overseas operations, where it generally faced fewer competitors. Dollar and unit sales also remained below 1929 levels, with the exception of 1937. Cost of goods sold as a proportion of net sales was relatively stable, moving pro-cyclically. Conversely operating expenses (mainly sales and administrative expenses) rose sharply during the Depression and, while they fell during the recovery, they remained substantially higher than for 1929.

\section{[Table 1 near here]}

Hoover's problems reflected the rigidities of its "core competencies/capabilities" interrelated, interdependent knowledge systems encompassing: technical systems; managerial systems; skills/knowledge base; and values and norms, that differentiate a company strategically. These tend to reflect the "imprint" of the company's founders, early leaders, and initial successes, which creates a "dominant logic" for the firm, based on a shared history. ${ }^{\text {lxxxvii }}$ The dynamic capabilities literature suggests that institutionalised capabilities 
may lead to "incumbent inertia" to environmental changes. Under such circumstances even minor innovations can undermine the value of the firm's deeply-embedded knowledge. ${ }^{\text {lxxxviii }}$ This is particularly true for "architectural innovations", which involve changes in how a product is configured, rather than innovations in individual components. Architectural innovations present incumbents with a subtle, but strong, challenge, as a firm's information channels, information filters, and accumulated "architectural knowledge", are all based around their existing configuration. ${ }^{\text {1xxix }}$

Hoover and Eureka faced such a challenge, in the form of Electrolux, which introduced the high-powered "tank-type" cleaner to the U.S. Market. This format dates back to the initial experimental phase of vacuum cleaner development in the 1900 s, though by the end of World War One the upright vacuum cleaner had emerged as the "dominant design" in the USA. Electrolux, formed in 1919 by the merger of two Swedish firms, Svenska Elektron $\mathrm{AB}$ and Lux $\mathrm{AB}$ (which had commenced manufacturing tank-type cleaners before the First World War) - continued to develop the tank-type format, which proved popular in Europe (possibly reflecting the smaller houses of many European countries). Their Model V cleaner was exported to the USA from 1924, but, both this and its successor Model 11 (introduced in 1927) were regarded as substantially underpowered in America, where they were mainly used as "dusters" for furniture and upholstery, or - as in New York, where sales were concentrated - for small apartments. ${ }^{\mathrm{xc}}$

\section{[Figure 4 near here]}

The Electrolux Model 12, launched in 1933, constituted the first high-powered tanktype cleaner on the U.S. market, combining both strong ease of use and dirt removal characteristics (see Figure 4). ${ }^{x c i}$ This rapidly catapulted Electrolux, which opened a factory in Old Greenwich, Connecticut, to manufacture it, in to the top rank of U.S. vacuum brands. ${ }^{\text {xii }}$ 
The Model 12 can be regarded as a "competence-destroying" technological discontinuity, in that it essentially represented a new product class - with the key characteristic of ease of use (especially for non-floor uses such as stairs, furniture, and curtains). ${ }^{\text {xiii }}$ While it never achieved the status of a "dominant design" (displacing the upright cleaner), it enjoyed huge popularity. In 1934 (the Model 12's first full sales year) Electrolux overtook Hoover for the first time, selling 136,687 vacuums for \$10,542,070, while Hoover sold 124,728 for $\$ 9,901,000 .^{\text {xciv }}$ In 1937 the Model 12 was replaced by the even more successful Model 30 - a design icon that had sold millions of units before being discontinued in 1954 .

Other durables sectors also witnessed new competitors during the Depression, using architectural innovations and leaner supply chains as the basis of their competitive advantage. Three of the four largest radio manufacturers of the 1920s failed to survive the Depression as significant players in the market, partly due to the development of the smaller, cheaper, "midget" radio format, aggressively marketed by new entrants such as Emerson and Philco. ${ }^{\mathrm{xcv}}$ The refrigerator and washing machine sectors also witnessed aggressive market entry, both by new manufacturers, such as Crosley, and - more importantly - retailer brands such as Sears Roebuck and Montgomery Ward, who cut prices chiefly through integrating production and distribution. ${ }^{\text {xcvi }}$ Successful entrants varied in their business models, but a common factor was squeezing sales/distribution costs.

Research commissioned by Ford, Bacon and Davis found that while Hoover owners were more enthusiastic about their vacuum's cleaning performance, Electrolux owners were more enthusiastic regarding ease of use - as Electrolux's "tank-type" design was easier to carry, easier to use with attachments, easier to clean furniture without moving it, easier to dispose of dirt, less noisy, and "not so hard on rugs". They concluded that: "Housewives are buying Electrolux because they prefer its ease of use features which are apparent to them compared to the cleaning efficiencies of the Hoover which are not so apparent." xcvii 
Hoover struggled to counter Electrolux's strong ease of use advantages, largely because they were inherent in to the tank-type format, which sucked in dirt through a long, light-weight hose. Switching to this format would involve abandoning much of their cumulative investments in vacuum features. For example their famous "positive agitation" system and their more recently-introduced "headlight" to illuminate dirt could not be transferred to a dust collector that was separated by the main body of the cleaner via a long hose. Yet Hoover's competitive problem was compounded by the fact that its sales demonstration continued to emphasise efficiency in removing dirt, apparently unaware of the need to modify its sales pitch to counter Electrolux's strong ease of use appeal. This was particularly important in what had become a mature product market, with most major brands being relatively successful in removing dirt compared to earlier cleaners.

In August 1936 Hoover introduced the Model 150 Ensemble, selling for $\$ 79.50$ plus $\$ 16.50$ for its cleaning tools (see Figure 4). This boasted a variety of new features, together with a classic modern design. Hoover advertised it as "The First Basically New Cleaner in 10 Years", emphasising its range of new mechanical innovations and features and, especially, its ease of use:

One little lift or push says 'How light. How easy it rolls.' Hoover engineers have brought into the home for the first time a new metal amazing for its lightness magnesium - until now used only in airplanes. One-third lighter than aluminium yet as strong. Only the new Hoover Cleaner offers the back-saving lightness of this new wonder-metal. ${ }^{\text {xcviii }}$

The heaviness of Hoover cleaners (compared to both tank-type and other upright brands) had always been Hoover's Achilles heel, leaving it open to periodic inroads in market share from firms with lighter models, such as Air-Way and Eureka in the early 1920s. ${ }^{\text {xcix }}$ The 
150 Ensemble weighed $16.25 \mathrm{lbs}$ (compared to $18 \mathrm{lbs}$ for its predecessor) and had various new ease of use features, including a simpler converter for attachments; a "time-to empty" signal, and an easy to empty filter bag. ${ }^{\mathrm{c}}$ However, its accompanying new salesman's booklet, Steps to the Hoover Sale, followed its predecessors in focusing on the Hoover's traditional strength of efficiency in drawing out dirt, demonstrated through various "tests" on the prospect's carpet. Ease of use was not mentioned until page 12, in the context of "improved features". ${ }^{\text {ci }}$ Moreover, the booklet made no mention of the need to modify the traditional Hoover demonstration to counter the competitive threat from Electrolux.

\section{The audit of Hoover}

In 1939 Hoover commissioned Ford, Bacon \& Davis to conduct a review of its operations and business methods, with a view to making recommendations on how to increase their effectiveness and profitability. The consultants' report emphasised Hoover's very low operating profit and return on investment relative to other leading consumer durables' firms. ${ }^{\text {cii }}$ This was supported by available data on large durables manufacturers. Hoover's profits over 1936-38 were found to average only 4.2 per cent of gross investment applicable to operations, compared to 48.0 per cent for Electrolux and 18.0 per cent for America's leading washer manufacturer, Maytag. ${ }^{\text {ciii }}$

Moreover, this problem could not be solved simply through higher sales. Using figures supplied by Hoover (including an element of forecast for higher sales levels), the report estimated that operating profit would rise from 3.1 per cent of sales at 150,000 cleaners per year to a peak of around 7.4 - 7.5 per cent at $210,000-240,000$ per year and then decline, to 6.9 per cent at an output of 300,000 . This reflected the large proportion of selling expenses that either varied directly with volume, or - such as bonuses to executives and senior managers - increased more than proportionately with volume. ${ }^{\text {civ }}$ Even these figures 
were said to be optimistic, as they assumed considerably higher relative sales for Hoover's more profitable "Norca" cleaners than had yet been achieved. Norcas had been introduced in 1937 for "over the counter" sales by department and similar stores and had a much higher profit rate than their Hoover branded cleaners, owing to lower distribution costs. ${ }^{\mathrm{cv}}$ If the projected Norca figures were excluded, net profit was substantially lower, peaking at 4.9 per cent of net sales.

Table 2 sets out the value chain for Hoover in 1938, together with estimates for Electrolux, provided by Ford, Bacon \& Davis. Hoover's net operating profit averaged only 2.2 per cent, compared to 20.4 -24.5 per cent for Electrolux. The source of the Electrolux data was not given, but its high profitability is supported by data from the Electrolux archives, showing a 1934 net profit ratio of 18.0 per cent. ${ }^{\text {cvi }}$ The value chain highlights two principal differences in cost structures, which account for most of Electrolux's higher profits. First, Electrolux provided higher commission to salesmen, but spent considerably less on supporting their activities through advertising, promotion, training, and supervision - the areas where Hoover had made progressively larger investments, to boost their market share. Secondly, while 15.8 per cent of Hoover's list price went to the participating retailer, under its resale system, Electrolux's direct sales supply chain had no dealer role and thus no costs under this heading.

\section{[Table 2 near here]}

The 15.8 per cent dealer discount was found, in a large proportion of cases, to be excessive relative to services rendered under the resale system (letting Hoover use their name when calling on prospects; allowing salesmen to solicit demonstrations in-store; stocking inventory; dealing with instalment credits; and bearing part of the cost of any machines that reverted back to them). It was noted that Electrolux had built up its market share without 
using dealers and market research indicated that many customers saw no advantage in the link with the dealer. The consultants thus recommended that Hoover should consider either discontinuing dealer participation or cutting its discount to dealers who did not render substantial sales promotion services from 15 per cent (excluding bonuses) to a maximum of 12.5 per cent. ${ }^{\text {cvii }}$

Ford, Bacon, and Davis noted that Hoover's brand managers believed they could secure the same sales volume without dealer participation. ${ }^{\text {cviii }}$ The same point had been made in May 1937 by C.B. Colston, Managing Director of Hoover's UK subsidiary, which produced and marketed Hoovers for sale in Europe and the British Empire (excluding Canada). Colston (arguably the most senior Hoover executive who was not a family member) believed their selling costs could be very substantially reduced by employing better salesmen, which would require a substantially higher commission rate. He suggested that they might follow the plan of British Hoover's Belgian sales subsidiary, where sales made directly by Hoover salesmen required no commission to dealers. E.L. Colston (Hoover UK's Sales Director), then explained "at very great length" that in Europe the dealer was often more of a handicap than an asset and was not essential to instalment credit as, after the first four months of the agreement, the finance company took responsibility for the loan. ${ }^{\text {cix }}$ However, this argument appears to have fallen on death ears (though it may account for a marginal reduction in dealer commission at some point in the late 1930s, from 14 to 13 per cent).

The consultants also questioned Hoover's long-standing assumption that increased sales depended primarily on increased manpower, showing that Hoover's annual sales correlated much better with the index of industrial production than with their number of salesmen. ${ }^{\text {cx }}$ This raised the question "Why is it necessary to have 3,937 salesmen in 1937 to sell the same volume as was sold by 1,859 salesmen in 1929." ${ }^{\text {cxi }}$ They argued that this mainly reflected the lower productivity of each salesman; obliging the company to increase the 
salesforce to maintain volume. As Table 3 shows, average weekly unit sales per salesman had fallen by 38 per cent and the real value of commission had declined to only 72 per cent of its 1929 value.

\section{[Table 3 near here]}

Declining salesmen's productivity was attributed in part to Hoover's heavy cost structure, compared to Electrolux, which enabled Electrolux to offer higher commission to salesmen- giving it a labour market advantage. Two other major vacuum firms that used direct sales, Air-way, and Rex Air, also had markedly higher commission rates than Hoover. ${ }^{\text {cxii }}$ Ford, Bacon and Davis also noted Electrolux's strong ease of use advantages, which were more obvious to the housewife than Hoover's superior cleaning efficiency. They recommended that Hoover should explore how to improve their ease of use advantages and adapt the sales process to further emphasise ease of use. They also had more general criticisms of Hoover's sales formula and training, arguing that the firm's sales manuals, other sales aids, and training programme had, in their opinion, "insufficient inspiration... The material appears to be of routine character to an extent likely to become boresome." cxiii

Perhaps their most fundamental criticism was that Hoover's senior managers focused on sales maximisation to such an extent that they neglected profitability: "The management is quite definitely volume-minded and is not sufficiently profit-minded. Whether the volume will produce adequate returns... has not been predetermined and no means such as thorough budgetary procedure... have been set up for predetermining profit objective for the business." "cxiv Hoover was found to have insufficient budgetary control, together with, "a most conspicuous lack of profitmindedness on the part of the organisation as a whole. In a two-day session of senior sales managers... only once was profitability of operations even mentioned and then there was no elaboration or discussion of it."cxv 
Ford, Bacon and Davis emphasised that direct selling per se was not the problem, despite its high costs, reflected in high prices $(\$ 69.00$ - $\$ 71.00$ for the median models of vacuum firms that relied mainly on direct selling, compared to $\$ 43.00-\$ 49.50$ for those using conventional retail channels). ${ }^{\text {cxvi }}$ They noted that vacuum companies which had switched to dealer distribution had failed to match the sales of Hoover and Electrolux, or the profit rate as Electrolux - a finding corroborated by the collapse in Eureka's sales volume following its termination of direct selling, discussed above. Interviews with retailers found no evidence of a trend towards growing over-the-counter distribution for vacuums; most admitted that in this sector demonstration was key, by showing the inefficiency of the housewife's existing cleaner (which was less evident than for an old refrigerator, washing machine, or radio), a result echoed by a 1940 U.S. government investigation. ${ }^{\text {cxvii }}$ While models lacking distinctive features had to be sold over the counter and compete on price, those with such features could most profitably be sold direct. Moreover, Hoover's Norca cleaners, together with sales to dealers of factory re-built traded-in Hoovers ("Specials") allowed them to tap the over-the-counter market without compromising their main brand. ${ }^{\text {cxviii }}$

Like Eureka before them, Hoover's managers reacted to their crisis in a manner that proved deeply counter-productive. Rather than implementing the consultant's key recommendation - that commission income should be redistributed from over-rewarded retailers to under-rewarded salesmen - Hoover's Sales Department tabled alternative proposals, which, perversely, maintained retailer commission rates and placed the main burden of cuts on the direct sales organisation. They offered savings of $\$ 439,000$ per year (trumping the $\$ 359,000$ estimated savings from Ford, Bacon and Davis's recommendations) through cuts to the Sales Department's and the Service Department's staff compensation plans; expense savings in these two departments; and a reduction in dealer trade-in participation. Detailed information on the revised compensation plans has not survived, 
though - given that they involved a substantial reduction in sales staff compensation (for equivalent sales) - they must have involved a reduction in salesmen's commission rates. ${ }^{\text {cxix }}$

The revised compensation plans were introduced in May $27^{\text {th }} 1940$. Despite the week ending April $27^{\text {th }} 1940$ having seen the highest sales in Hoover's prior history, the new system was followed by a sales slump, which was at least partly attributed to this new plan. ${ }^{\text {cxx }}$ Further modifications to sales policies were cut short in 1941, when Hoover was called on to make an early start in munitions production, even before the USA formally entered the War. Their main contract involved manufacturing (eventually) 25 million highly-secretive variable time proximity fuses - a task which paid testament to their considerable engineering skills (having been likened in difficulty to compressing the components of an aircraft engine into the shape of an ice cream cone). ${ }^{\text {cxxi }}$

However, the problems identified by the consultants continued to plague Hoover after World War Two; in 1954 profits amounted to only three per cent of sales, while Hoover's market share had fallen to nine percent. ${ }^{\text {cxxii }}$ Hoover's engineers again came to the rescue, ironically, through finally developing a tank-type cleaner - the Hoover Constellation. Claimed to be the quietest vacuum on the market, the Constellation boasted a highly innovative mobility feature, the "Air-ride" which floated the cleaner like a hovercraft, using its own exhaust as the air source, while a striking space-age circular design accentuated its novelty. The Constellation improved Hoover's market share - though it continued to be plagued by low profitability. ${ }^{\text {cxxiii }}$

\section{Conclusion}

Hoover's declining profitability and the collapse of Eureka's direct sales system illustrate how previously successful corporate practices, performance benchmarks, and value chain relationships can develop rigidities over time, reducing responsiveness to changes in 
market or competitive conditions. Moreover, their reactions to their respective crises suggest that these same rigidities inhibited them from acknowledging and addressing the fundamental problems underlying their falling profitability. Such behaviour is by no means exceptional; the "threat rigidity" literature identifies numerous examples of companies reacting to crises via policies that act to compound their difficulties (and predictably so) - typically explained in terms of a tendency for organizations to behave conservatively rather than innovatively in threatening situations - especially under conditions of prior organizational rigidities. ${ }^{\text {cxxiv }}$ Such conservative responses were also typical of incumbents in other durables sectors during the Depression, particularly the dominant radio firms of the 1920s, which failed to effectively react to new entrants that capitalised on leaner supply chains and cost-reducing architectural innovations.

As Tushman and Anderson have noted, "liabilities of age and tradition" can constrain incumbents facing competence-destroying discontinuities. ${ }^{\text {cxxv }}$ Hoover in particular appears to have fallen into a "competency trap": its core competencies - extensive sales support investment (including dealer participation), and formidable R\&D activities focused primarily on more efficient dirt removal, in conjunction with assumptions that profits were driven by sales, and, in turn, by manpower - having become core rigidities. ${ }^{\text {cxxvi }}$ As Teece, Pisano, and Shuen note, "In dynamic environments, narcissistic organizations are likely to be impaired."cxxvii Values which had initially partly served to "sell" Hoover's product, "system" and "mission" to its salesforce had become "core" to all levels of the company, making even a cut in salesforce compensation than ran directly counter to the recommendations of their consultants preferable to the alternative - departing from the system that had represented the "gospel" of vacuum salesmanship for most Hoover executives throughout their working lives. 
Table 1: Hoover's sales, costs, and profits, 1929-1939

\begin{tabular}{|c|c|c|c|c|c|c|c|}
\hline \multirow[t]{2}{*}{ Year } & \multicolumn{2}{|c|}{ Net sales } & \multicolumn{2}{|c|}{ Costs to net sales ratios } & \multirow[b]{2}{*}{ Total } & \multicolumn{2}{|c|}{ Income to sales ratios } \\
\hline & Dollars & Units & Cost of goods sold & Operating expenses & & Operating* & Net** \\
\hline 1929 & $14,691,000$ & 189,859 & 28.6 & 57.2 & 85.8 & 13.5 & 15.4 \\
\hline 1930 & $13,211,000$ & 168,067 & 27.8 & 67.4 & 95.2 & 4.2 & 9.0 \\
\hline 1931 & $11,084,000$ & 133,859 & 26.5 & 71.6 & 98.1 & 1.1 & 6.1 \\
\hline 1932 & $8,998,000$ & 123,895 & 27.4 & 75.2 & 102.6 & -3.9 & 1.3 \\
\hline 1933 & $7,854,000$ & 104,125 & 24.9 & 73.0 & 97.9 & 0.6 & 7.4 \\
\hline 1934 & $9,901,000$ & 124,728 & 26.7 & 72.6 & 99.3 & 0.4 & 10.0 \\
\hline 1935 & $11,420,000$ & 147,384 & 29.2 & 66.3 & 95.5 & 4.2 & 8.0 \\
\hline 1936 & $13,125,000$ & 168,939 & 30.8 & 66.0 & 96.8 & 2.8 & 5.9 \\
\hline 1937 & $15,116,000$ & 201,275 & 29.9 & 63.4 & 93.3 & 6.3 & 9.5 \\
\hline 1938 & $12,665,000$ & 162,278 & 29.8 & 71.3 & 101.1 & -1.6 & 14.1 \\
\hline Average & $11,806,000$ & 152,441 & 28.2 & 68.4 & 96.6 & 3.4 & 9.1 \\
\hline
\end{tabular}

Sources, unit sales, HHC, Hoover chronology by Lee P. Heinrich (undated, c. 1940s); other data, Ford, Bacon, and Davis report, Volume 2, Exhibit 1.

Notes: * Net sales minus total costs, plus other net income affecting operations. ** Operating income plus other net income, before taxes. 
Table 2: The value chains for Hoover and Electrolux in 1938 (percentage of net sales)

\begin{tabular}{|l|r|r|}
\hline Costs: & Hoover & Electrolux \\
\hline Manufacturing & 22.6 & $20.0-22.6$ \\
\hline Dealer discounts & 15.8 & 0.0 \\
\hline Sales management \& administration & & \\
\hline Branch and district sales organisation & 12.9 & n.a. \\
\hline Other & 12.1 & na. \\
\hline Total & 25.0 & $23.5-25.0$ \\
\hline Sales support activities & & \\
\hline Sales personnel education & 1.0 & 0.0 \\
\hline Sales promotion & 0.9 & 0.5 \\
\hline Advertising & 3.6 & 1.0 \\
\hline Supervision & 7.2 & 3.0 \\
\hline Total & 12.7 & 4.5 \\
\hline Salesmen's remuneration & 21.7 & 27.5 \\
\hline Total costs & 97.8 & $75.5-79.6$ \\
\hline Operating Profit & 2.2 & $20.4-24.5$ \\
\hline
\end{tabular}

Source: HCC, Ford, Bacon, and Davis report, 71.

Notes: Electrolux's figures are estimates by the consultants. 
Table 3: Comparison of Hoover's salesmen's productivity, 1929 and 1937

\begin{tabular}{|l|r|r|}
\hline Year & 1929 & 1937 \\
\hline Number of cleaners sold & 189,755 & 200,663 \\
\hline Number sold by Hoover salesmen & 149,189 & 194,990 \\
\hline Number of salesmen on list & 1,859 & 3,937 \\
\hline Cleaners sold per man per week & 1.54 & 0.95 \\
\hline Average unit price (\$) & 79.43 & 73.84 \\
\hline Retail billings per man per week (\$) & 123.00 & 70.00 \\
\hline $\begin{array}{l}\text { Commission rate (percent; net, after trade-in } \\
\text { participation) }\end{array}$ & 18.00 & 20.02 \\
\hline Commission per man per week (\$) & 22.10 & 14.01 \\
\hline Real value of commission per man-week (\$) & 22.10 & 15.83 \\
\hline
\end{tabular}

Source: HCC, Ford, Bacon, and Davis report, $87 \& 162$. 
Figure 1: Eureka Vacuum Cleaner Co. outside sales organisation, May 1927.

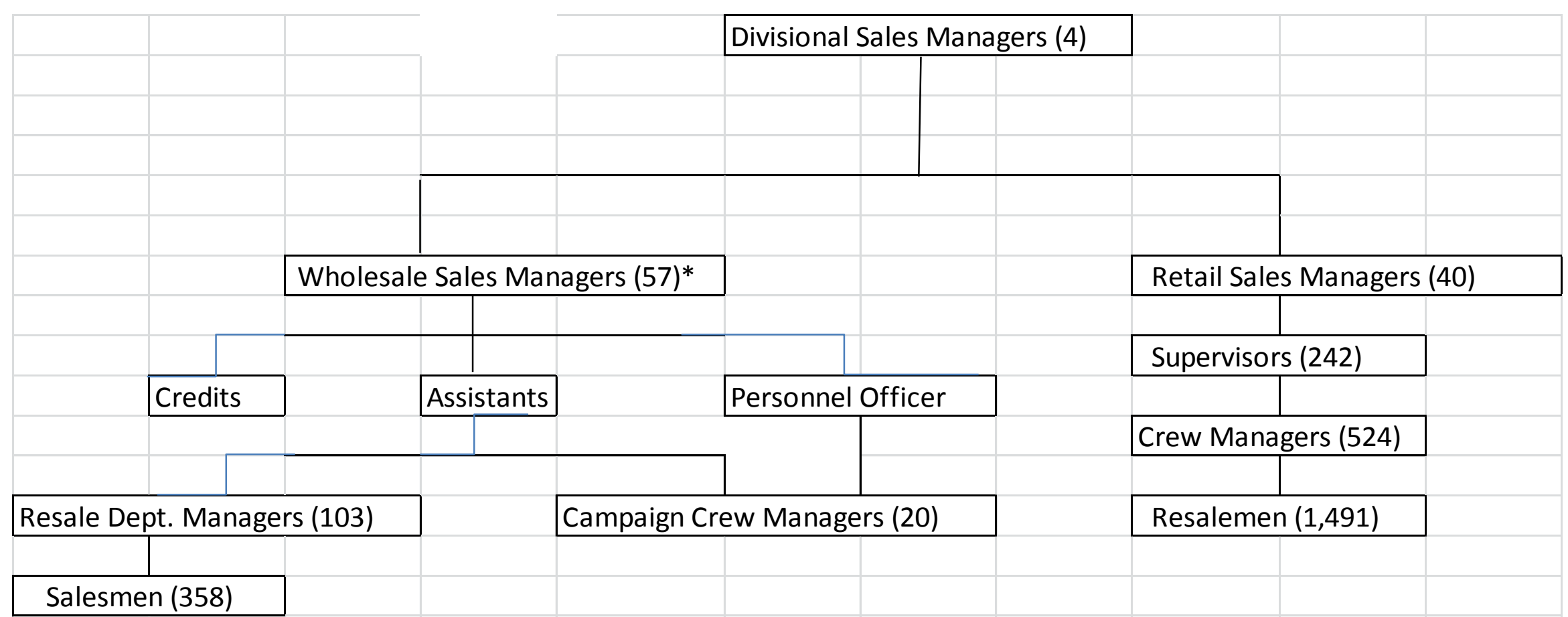

Source: Hagley Museum Library \& Archives, 2069/9/16, Victor Talking Machine Co., Consignment selling, Victor Talking Machine Co. field survey, 192627. Reports of interview with Mr C.W. Phister, Eureka Vacuum Cleaner Co., 26 May 1927.

Notes: *Wholesale sales manager numbers include assistants. Eureka also employed a staff of eight auditors and, at each important branch, a personnel officer. 
Figure 2: Crowds assembled for one of the early Hoover international convention parades

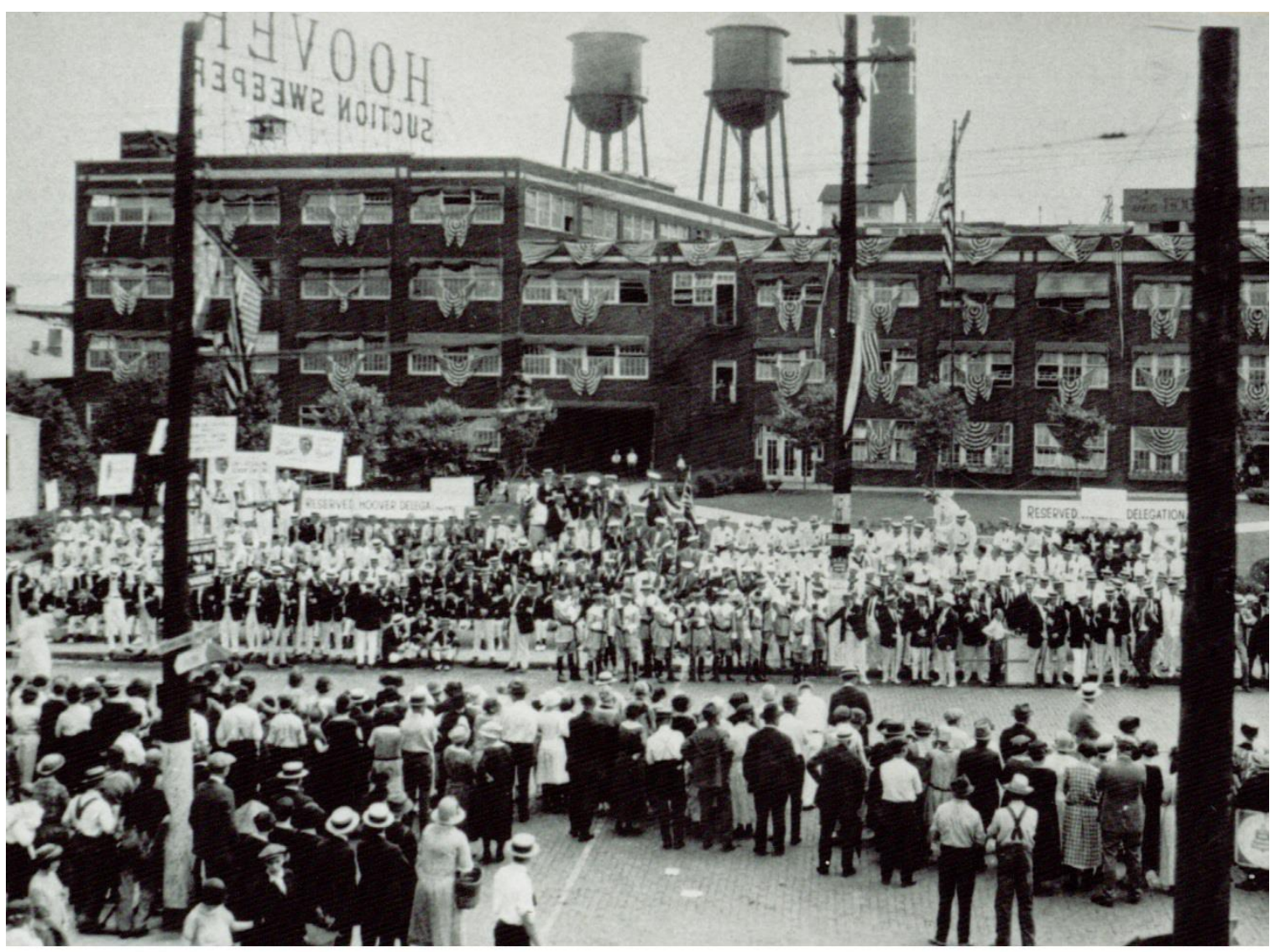

Source: HHC, Hoover Co. "Pictorial History of Hoover International Conventions", n.d., c. 1923. 
Figure 3: Costs and profits as a proportion of net sales, and costs per machine, for Eureka, $1921-29$

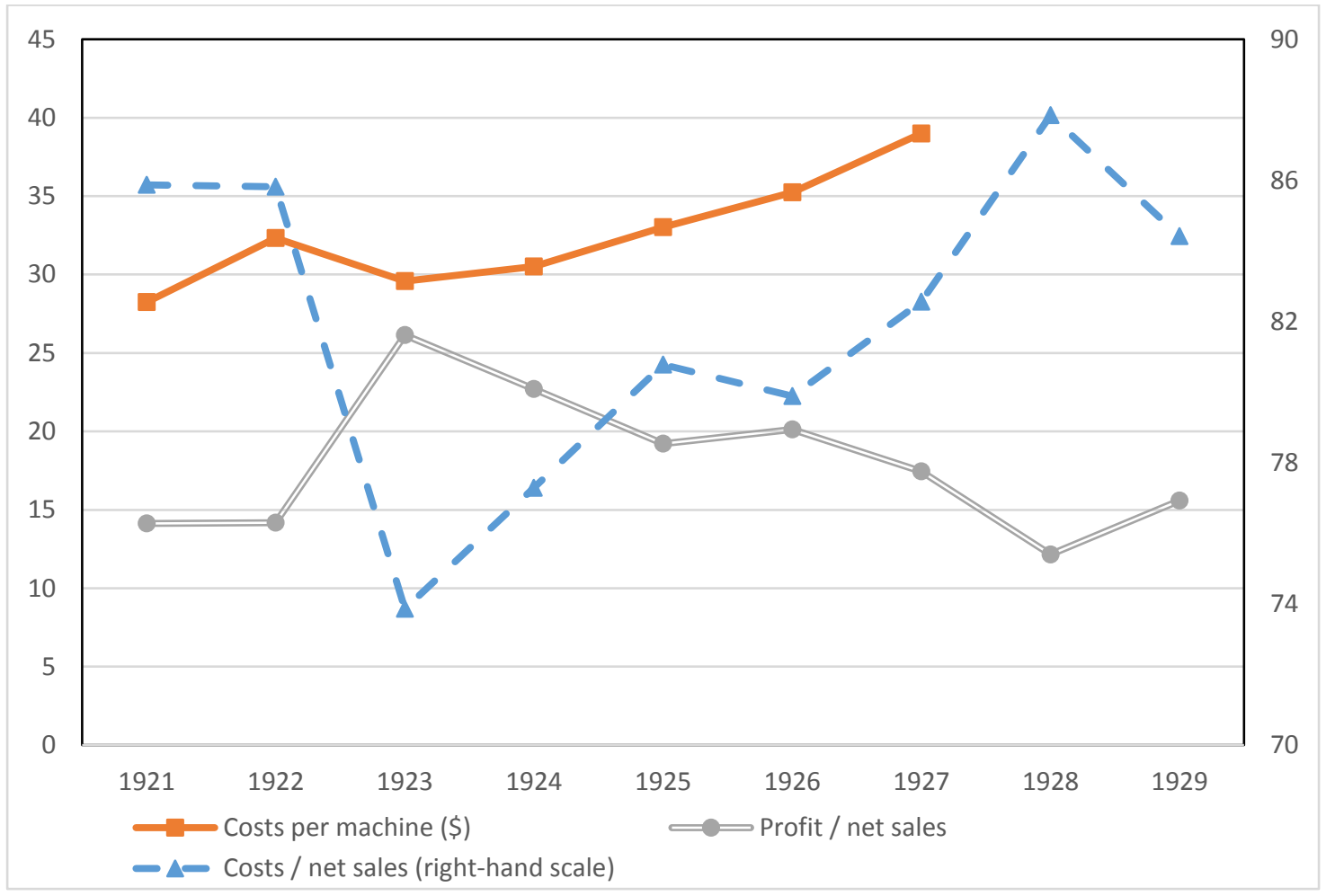

Sources: 1921-22, Hagley Museum Library \& Archives, 2069/9/16, Victor Talking Machine Co., Consignment selling, Victor Talking Machine Co. field survey, 1926-27. Reports of interview with Mr C.W. Phister, Eureka Vacuum Cleaner Co., 26 May 1927; 1923-29, Moody's Investment Service, Moody's Manual of Investments. American and Foreign. Industrial Securities (New York: Moody's); 1929, 54; 1930, 604.

Notes: 1929 figures include Eureka's new London sales subsidiary. Costs include depreciation. Profits are shown before deductions of fixed charges and federal taxes. 
Figure 4: The Electrolux Model 12 and the Hoover Model 150 Ensemble.

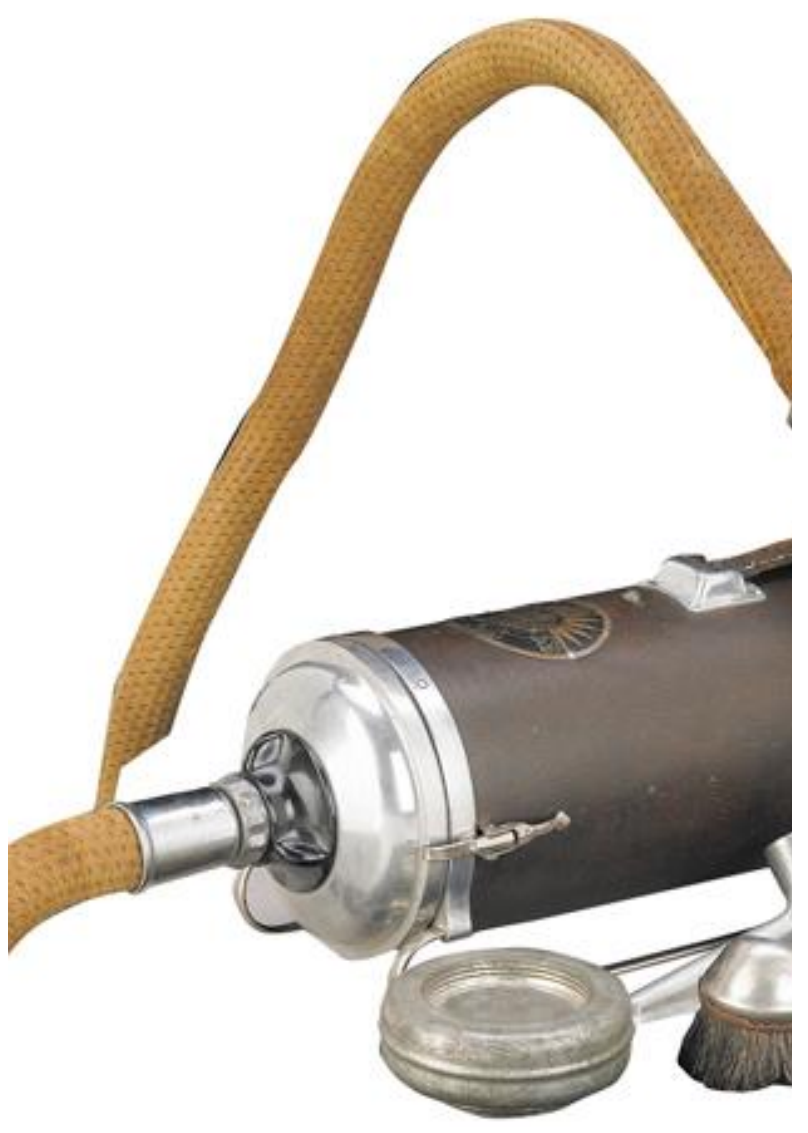

Reproduced by kind permission of Tom Gasko.

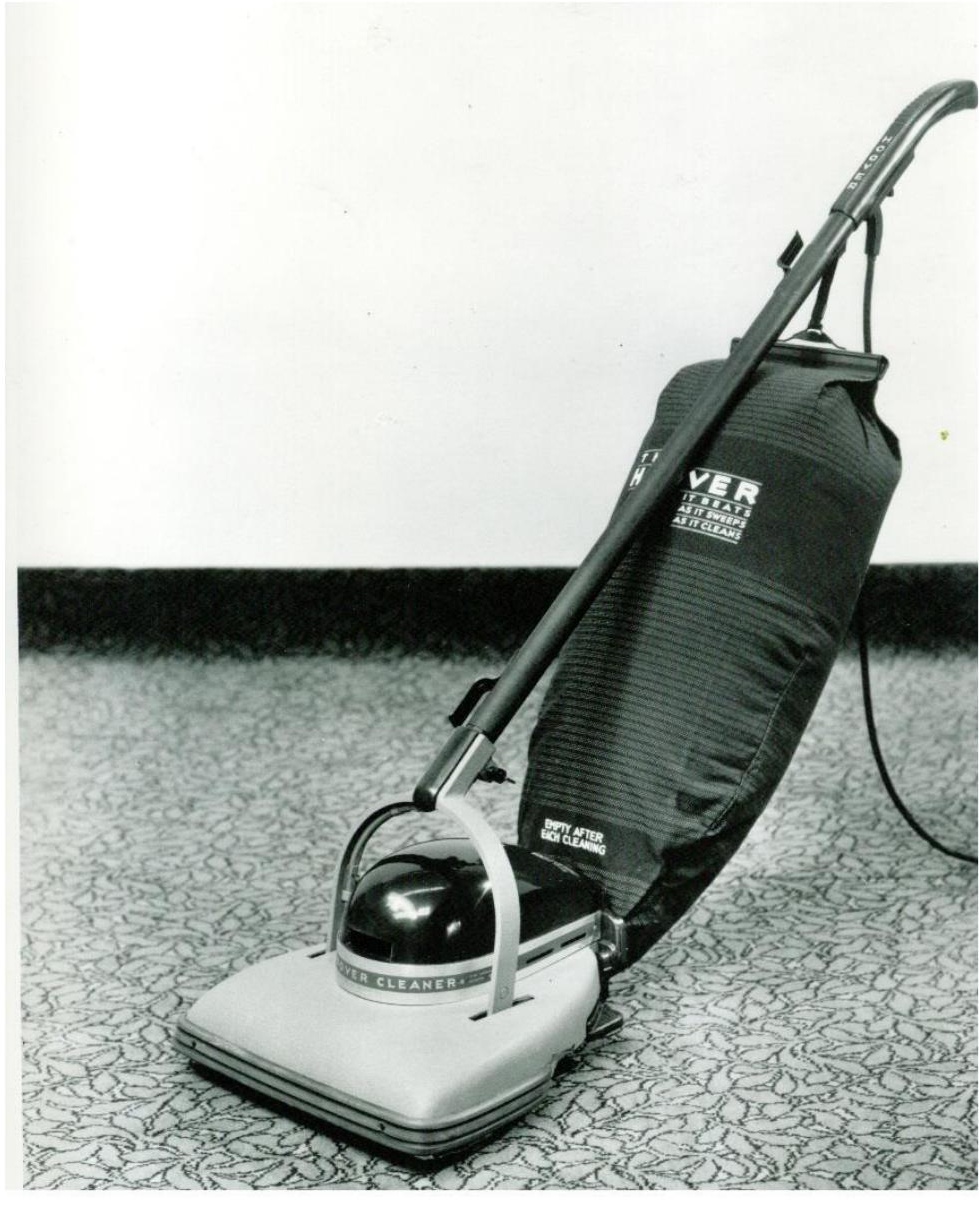

Photo courtesy of Hoover Historical Center/Walsh University, North Canton, Ohio. 
${ }^{i}$ D. Leonard-Barton, "Core Capabilities and Core Rigiditis: a Paradox in Managing New Product Development," Stategic Management Journal, 13 (1992):111-125, p.112; David J. Teece, Gary Pisano, and Amy Shuen, 'Dynamic Capabilities and Strategic Management,' Strategic Management Journal, 18 (1997), 509-33, p. 519.

ii Clayton M. Christensen, Thomas Bartman, and Derek van Bever, "The Hard Truth about Business Model Innovation," Sloan Management Review, 58 (2016), 30-40.

iii See Fances J. Miliken and Luis L. Martins, "Searching for Common Threads: Understanding the Multiple effects of Diversity in Organizational Groups," Academy of Management Review, 21 (1996): 402-433; Cindy P. Lindsay, "Paradoxes of Organizational Diversity,” Journal of Management Issues, 5 (1993): 547-566; Andreas Schwab, James D. Werbel, Heike Hofmann, and Paulo L. Henriquez, "Managerial Gender Diversity and Firm Performance: an Integration of Different Theoretical Perspectives, Group \& Organization Management, 41 (2016): 5-31.

iv See Miliken and Martins, "Searching for Common Threads," 410-416.

v Alan A. Raucher, "Dime Store Chains: the Making of Organization Men, 1880-1940," Business History Review, 65 (1991): 130-163, pp. 138-52.

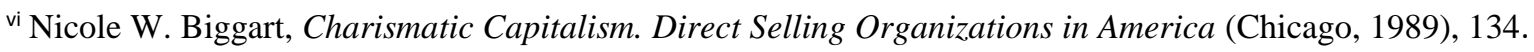

vii See Donna M. Randall, "Commitment and the Organisation: the Organizational Man Revisited,' Academy of Management Review, 12 (1987): 460-71.

viii Peter Scott, The Market Makers. Creating Mass Markets for Consumer Durables in Inter-war Britain (Oxford, 2017), 207-216.

${ }^{\text {ix }}$ Federal Trade Commission, Report on the House Furnishings Industry. Volume III: Kitchen Furnishings and Domestic Appliances (Washington DC), 15.

${ }^{x}$ Carroll Gantz, The Vacuum Cleaner. A History (Jefferson N.C., 2012), 70.

xi Biggart, Charismatic Capitalism, 25-27; Ruth S. Cowan, More Work for Mother. The Ironies of Household Technology from the Open Hearth to the Microwave (New York, 1983), 151-191; Susan Strasser, Never Done. A History of American Housework (New York, 1982), 206-223.

xii Phyllis Palmer, Domesticity and Dirt. Housewives and Domestic Servants in the United States, 1920-1945 (Philadelphia, 1989), 33. 
xiii See Peter Scott and James T. Walker, “Bringing Radio into America's Homes: Marketing New Technology in the Great Depression," Business History Review, 90 (2016): 251-76.

${ }^{\text {xiv }}$ Frank G. Hoover, Fabulous Dustpan. The Story of the Hoover (Cleveland, 1955), 161.

${ }^{\mathrm{xv}}$ Ibid, 128.

${ }^{\text {xi }}$ Gantz, Vacuum Cleaner, 78.

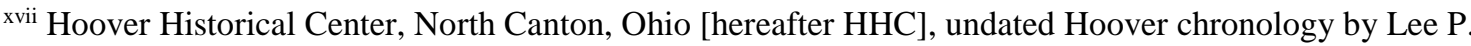
Heinrich, c. 1940s, 73.

xviii David A. Hounshell, From the American System to Mass Production 1800-1932 (Baltimore, 1984), 5-10.

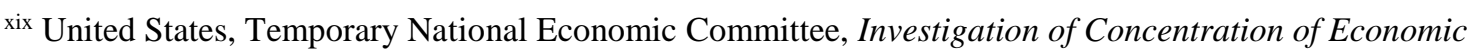
Power. Monograph No. 1. Price Behavior and Business Policy (Washington: USGPO, 1940), p. 134.

xx Douglas E. Eberhart, “William Henry Hoover: His Life, His Business, His Success,” unpublished BA thesis, (Princeton University, 1985), 85.

xxi Hagley Museum Library \& Archives [hereafter Hagley], 2069/9/16, Victor Talking Machine Co., Consignment selling, Victor Talking Machine Co. field survey, 1926-27. Reports of interview with Mr C.W. Phister, Eureka Vacuum Cleaner Co., 26 May 1927.

xxii Ibid.

xxiii Scott, Market Makers., 217-219.

${ }^{\text {xxiv }}$ HHC, Filing Cabinet 78.033\#52, Ford, Bacon \& Davis, "Report . Business and Sales Operations, The Hoover Company, North Canton, Ohio,” 14 Feb. 1940 [hereafter HHC, Ford, Bacon and Davis report], Vol. 1, $156-7$

${ }^{x x v}$ Ibid.

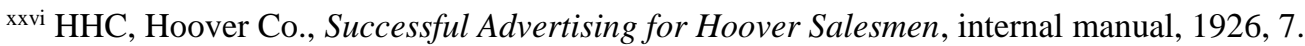

${ }^{\text {xxvii }}$ HHC, Ford, Bacon \& Davis report, Vol. 1, 153.

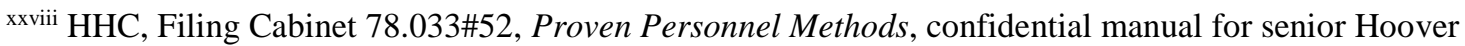
managers, December 1934, 1.

${ }^{\text {xxix }}$ HHC, Ford, Bacon \& Davis report, Vol. 1, 9.

${ }^{\mathrm{xxx}}$ Angel Kwolek-Folland, Engendering Business. Men and Women in the Corporate Office 1870-1930 (Baltimore, 1994), 84.

xxxi See Raucher, "Dime Store Chains”, 139-151. 
xxxii Hoover, Fabulous Dustpan, 167-8; Hagley, 2069/9/16, Victor Talking Machine Co., "Consignment Selling," Victor Talking Machine Co. field survey, 1926-27. Reports of interview with Mr C.W. Phister, Eureka Vacuum Cleaner Co., 26 May 1927.

xxxiii See Raucher, "Dime Store Chains,” 131.

xxxiv Kwolek-Folland, Engendering Business, 75-77.

${ }^{x x x v}$ Wright State University, Special Collections and Archives, unpublished draft history of Frigidaire, 1964, A2/2, Frigidaire history, A2/2, Salesmanship chapter, 1-2.

xxxvi Walter A. Friedman, Birth of a Salesman. The Transformation of Selling in America (Cambridge, Mass., 2004), 130. For Hoover's development of factory welfare and recreational facilities, see Eberhart, "William Henry Hoover," 55.

xxxvii McLean County Museum of History, Bloomington Illinois, Eureka Williams Electrolux Archive, Folder 2, “The Eureka Salesman”, manual for Eureka dealers and salesmen, 1936, 31; Box 3, Eureka Morning News (13 Feb. 1928), 1.

xxxviii Kwolek-Folland, Engendering Business, 75-77; Stephen P. Waring, Taylorism Transformed. Scientific Management Theory since 1945 (Chapel Hill, NC, 1991), 106.

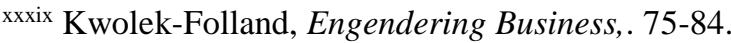

${ }^{\mathrm{xl}}$ Hoover, Fabulous Dustpan, 166.

xli Ibid, 159 .

xlii Francesca Carnevali, "Social Capital and Trade Associations in America, c. 1860-1914: a Microhistory Approach,” Economic History Review, 64 (2011): 905-928, p. 916.

xliii Clark Davis, Company Men. White-Collar Life and Corporate Cultures in Los Angeles 1892-1941 (Baltimore, 2000), $103 \&$ 172-3.

${ }^{\text {xliv }}$ HHC, Harry Frease et. al., 'The History of the Hoover Company', unpublished typescript, n.d., c. 1940s, 109. xlv Ibid, 118.

xlvi Ibid, 123.

xlvii Biggart, Charismatic Capitalism, 127 \& 152-4.

xlviii Kwolek-Folland, Engendering Business, 161-2; Olivier Zunz, Making America Corporate 1870-1920

(Chicago, 1990), 186; Wright State University Archives, Frigidaire history, A2/2, Salesmanship chapter, pp. 1618.

xlix HHC, Frease et. al., "History of the Hoover Company," 161. 
${ }^{1}$ Andrew Popp, "Custom and Spectacle: the Public Staging of Business Life,' 29-53 in Paolo Di Martino, Andrew Popp, and Peter Scott (eds), People, Places and Business Cultures. Essays in Honour of Francesca Carnevali (Woodbridge, 2017), 51-53.

${ }^{\text {li }}$ Zunz, Making America Corporate, 181-5.

lii Zunz, Making America Corporate, 188; Davis, Company Men, 42-9.

liii HHC, 'Hoover Sweepings,' Vo. 1, No. 7 (1911).

liv Davis, Company Men, 109-120; Elspeth H. Brown, The Corporate Eye. Photography and the Rationalization of American Commercial Culture 1884-1929 (Baltimore, 2005), 138-142.

${ }^{\text {Iv }}$ Biggart, Charismatic Capitalism, 1989, 85.

lvi HHC, Filing Cabinet 78.033\#52, Hoover Co., Sales Educational Dept., Sales Meetings for Hoover Managers, manual, 1925.

lvii Ibid.

lviii Ibid. Emphasis in original.

lix Kenneth Lipartito, "From Social Capital to Social Assemblage," 177-191 in Paolo Di Martino, Andrew Popp, and Peter Scott (eds), People, Places and Business Cultures. Essays in Honour of Francesca Carnevali (Woodbridge, 2017).

${ }^{1 x}$ Ibid, 187.

${ }^{1 x i}$ Clayton M. Christensen, Thomas Bartman, and Derek van Bever, "The Hard Truth about Business Model Innovation," Sloan Management Review, 58 (2016), 30-40.

lxii Friedman, Birth of a Salesman, 195-6.

Ixiii HHC, The Standard Way, Hoover salesman's manual, 1932, p. 1.

${ }^{1 x i v}$ Hoover Co., Steps to the Hoover Sale (North Canton, Oh., 1936), held privately by the author.

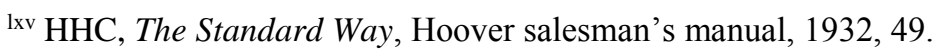

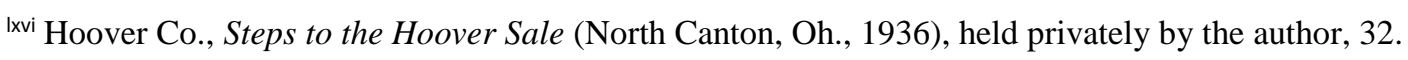

1xvii Kwolek-Folland, Engendering Business, p. 89.

Ixviii For exclusionary strategies in personnel managment, see Nikki Mandell, The Corporation as Family: The Gendering of Corporate Welfare, 1890-1930 (Chapel Hill, NC, 2002).

lxix HHC, Filing Cabinet 78.033\#52. Sales activities file, advertising charts, no date, c. 1931. Figures for 19191926 and 1929 read from graph. 


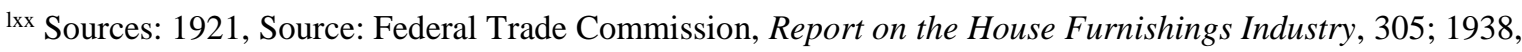
HHC, Ford, Bacon, and Davis report, 71.

${ }^{\text {lxxi }}$ Zunz, Making America Corporate, 83.

Ixxii Ibid, 83-90.

lxxiii Amit Jain, "Learning by Hiring and Change to Organizational Knowledge: Countering Obsolescence as Organizations age", Strategic Management Journal, 37 (2016), 1667-1687.

lxxiv Raucher, "Dime Store Chains,” 138-52.

${ }^{1 x x v}$ Leonard-Barton, "Core Capabilities and Core Rigidities,” 118-121.

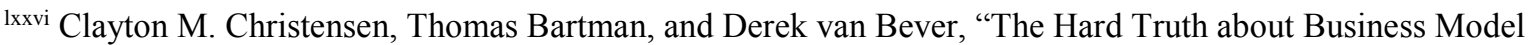
Innovation," Sloan Management Review, 58 (2016), 30-40.

Ixxvii Ibid, p. 35.

lxxviii Gantz, Vacuum Cleaner, p. 132.

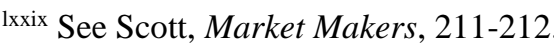

Ixxx "Eureka Vacuum Cleaner Company. Discontinuance of Branches and Sub-branches (case)", 79-82 in University of Michigan, School of Administration, Announcement 1934-35, (Ann Arbor, 1934), 79.

${ }^{1 \times x x i}$ United States, Temporary National Economic Committee, Investigation of Concentration of Economic Power, 146

lxxxii “Eureka," 79-82 in University of Michigan, School of Administration, Announcement, 79-80.

lxxxiii O. Fred Rost, Distribution Today (New York, 1933) 113; Moody's Investment Service, Moody's Manual of Investments. American and Foreign. Industrial Securities (New York, 1931), 1350.

Ixxxiv `Electrical Merchandise Review and Forecast,' Electrical Merchandising (January 1934), 29-33, p. 31. Ixxxv “Eureka Williams. Its Oil Burners are still Selling Easily but for Vacuum Cleaners the Buyer’s Market is Here Again,” Fortune (Dec. 1947), 108-190, pp. 108 \& 111-12.

${ }^{\text {Ixxxi }}$ Sources: industry-wide sales, Elecrical Merchandising (January 1942), 607; Hoover sales, HHC, Hoover chronology by Lee P. Heinrich (undated, c. 1940s).

lxxxvii Leonard-Barton, "Core Capabilities and Core Rigidities," 114; Mary Tripsas and Giovani Gavetti, "Capabilities, Cognition, and Inertia: Evidence from Digital Imaging,” Strategic Management Journal, 21 (2000), 1147-61, p. 1148. 
lxxxviii Leonard-Barton, “Core Capabilities and Core Rigidities,” 112; Teece, Pisano, and Shuen, "Dynamic Capabilities," 519.

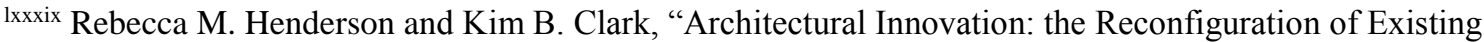
Product Technologies and the Failure of Established Firms," Administrative Science Quarterly, 35 (1990), 9-30.

${ }^{x c}$ Gantz, Vacuum Cleaner, pp 60-94.

xci Ibid, 93-94.

xcii Ibid.

xciii Michael Tushman and Philip Anderson, “Techonological Discontinuities and Organizational Environments," Administrative Science Quarterly, 31 (1986), 439-465, p. 442.

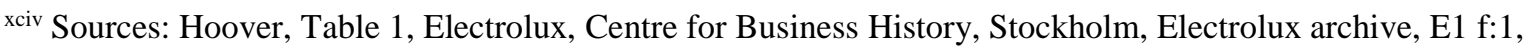
statement on Eletrolux Corporation of New York, $8^{\text {th }}$ October 1935, accompanying a letter from (signature illegible) Higgson \& Co., to H.G. Faulkner. No Electrolux data are available for later years.

${ }^{\text {xcv }}$ See Scott, Market Makers, 122-129.

xcvi The Nudes Have It,' Fortune Magazine (May 1940), 73-111.

xcvii HHC, Ford Bacon \& Davis report, Vol. 1, 119-120.

xcviii MiSci Museum, Schenectady, NY, Gerald Swope Papers, 201.2 Q, Hoover advert from, Saturaday Evening Post $17^{\text {th }}$ October 1936.

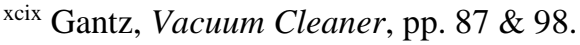

c HHC, Frease et. al., "History of the Hoover Company,” 217-18; Gantz, Vacuum Cleaner, 107-8.

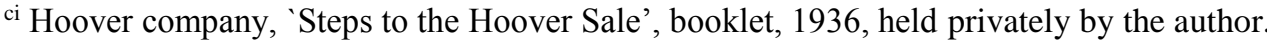

${ }^{\text {cii }}$ HHC, Ford, Bacon \& Davis report, Vol. 1, 3-6.

ciii Ibid, 10 \& 31-33.

civ Ibid, 66-69.

${ }^{c v}$ HHC, Frease et. al., "History of the Hoover Company," 222-223.

${ }^{\text {cvi }}$ Centre for Business History, Stockholm, Electrolux archive, E1 f:1, statement on Eletrolux Corporation of New York, $8^{\text {th }}$ October 1935, accompanying a letter from (signature illegible) Higgson \& Co., to H.G. Faulkner. ${ }^{\text {cvii }}$ HHC, Ford, Bacon \& Davis report, Vol. 1, 7-8 \& 106-7.

cviii Ibid, 72 . 


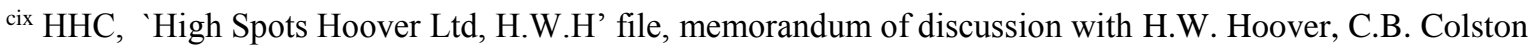
and E.L. Colston, 18 May 1937.

${ }^{c x}$ For example, HHC, W.W. Steele, “Manpower Comes First!,” Hoover Manager (November 1932), 1.

${ }^{\text {cxi }}$ HHC, Ford, Bacon \& Davis report, Vol. 1, 87.

cxii Ibid, $100 \& 161$.

cxiii Ibid, 129.

cxiv Ibid,. 9-10.

${ }^{c x v}$ Ibid, 62.

${ }^{\text {cxvi }}$ Ibid,. 100.

cxvii Ibid, 103; United States, Temporary National Economic Committee, Investigation of Concentration of Economic Power, 140.

${ }^{\text {cxviii }}$ HHC, Ford, Bacon \& Davis report, Vol. 1, 104.

${ }^{\text {cxix }}$ HHC, Filing Cabinet 78.033\#52, Hoover Co. Board minutes, 2-3 May 1940 and 20 June 1940.

${ }^{\text {cxx }}$ HHC, Frease et. al., "History of the Hoover Company," 233.

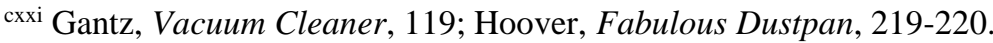

cxxii Gantz, Vacuum Cleaner, 132.

cxxiii Ibid, 129-30.

${ }^{\text {cxxiv }}$ Barry M. Shaw, Lance E. Sandelands, and Jane E. Dutton, "Threat-rigidity Effects in Organizational Behavior: a Multilevel Analysis, Administrative Science Quarterly, 26 (1981), 501-524; Olav Muurlink, Adrian Wilkinson, David Peetz, and Keith Townsend, "Managerial Autism: Threat-rigidity and Rigidity’s Threat," British Journal of Management, 23 (2012), S74-S87.

cxxv Tushman and Anderson, "Techonological Discontinuities,” 460-461.

cxxvi Tripsas and Gavetti, ‘Capabilities, Cognition, and Inertia,’ 1147.

cxxvii Teece, Pisano, and Shuen, “Dynamic Capabilities,” 521. 